\title{
Should Cross-Border Banking Benefit from the Financial Safety Net? ${ }^{1}$
}

\author{
Ata Can Bertay \\ Ozyegin University and World Bank \\ Asli Demirgüç-Kunt \\ World Bank \\ Harry Huizinga \\ Tilburg University and CEPR
}

This draft: January 2016

\begin{abstract}
Using bank-level data from 84 countries, we find that a higher degree of bank internationalization is associated with higher interest expenses. Internationalization is proxied by a bank's share of foreign liabilities in total liabilities or a Herfindahl index of international liability concentration. Bank interest expenses rise relatively more with internationalization if the bank is underperforming or headquartered in a country with weak public finances, and especially at times of weak world output growth. These results suggest that liability holders of distressed internationalized banks expect less from the financial safety net since lack of an efficient recovery and resolution regime for international banks can make their insolvency very costly to deal with.
\end{abstract}

Key words: Bank bailouts, International burden sharing, Cross-border banking JEL Classification: F36, G21, G28

1 Bertay: Ozyegin University and World Bank (Ata.bertay@ozyegin.edu.tr); Demirgüç-Kunt: World Bank (Ademirguckunt@worldbank.org); Huizinga: Tilburg University and CEPR (Huizinga@uvt.nl). We thank an anonymous referee, Stijn Claessens, Alex Popov, Alberto Pozzolo, Tomasz Wieladek and participants at the conference on the Economics of Global Banking in April 2013 at the London Business School and the $10^{\text {th }}$ Annual Seminar on Risk, Financial Stability and Banking of the Banco Central do Brasil for useful comments and suggestions. This paper's findings, interpretations, and conclusions are entirely those of the authors and do not necessarily represent the views of the World Bank, its Executive Directors, or the countries they represent. 


\section{Introduction}

The resolution of a distressed international bank is potentially plagued by a conflict of interest about international burden sharing among national authorities, which often makes it an uncertain and costly process. This can also make the financial safety net coverage of international banks less certain compared to domestic banks, possibly increasing their funding costs. In this paper we examine if a bank's funding costs are associated with its degree of internationalization and whether this reflects international banks' differential access to the financial safety net.

Using bank-level data for 84 countries over the 1999-2009 period, we show that a bank's cost of funds rises significantly with its internationalization. Specifically, banks with a higher share of foreign liabilities in overall liabilities pay higher interest expenses, which is consistent with a less generous financial safety net coverage for cross-border banks. Moreover, we show that a bank's funding costs decline with a Herfindahl index of liability concentration among the countries where it operates. A higher international liability concentration increases the incentives for the affected public authorities to provide bailout funding to a distressed bank, thereby potentially limiting expected losses for bank liability holders.

We provide several pieces of evidence that the higher funding costs of international banks reflect the less generous safety net support available to them. Uncertain access to the financial safety net is especially damaging for underperforming banks, as these are more likely to require safety net support. Confirming this conjecture, we find that a bank's cost of funds increases with its share of foreign liabilities especially if it is not performing well. Similarly, the cost of funds for an underperforming bank declines more with the international concentration of its liabilities.

To further test whether international banks expect less from the financial safety net, we split the overall sample into banks headquartered in fiscal-deficit and fiscal-surplus countries. 
International banks located in countries experiencing fiscal deficits may be able to rely on the financial safety net to a lesser extent, since these countries may be unable or unwilling to shoulder the cost of bailing out international banks. Indeed, we find that the estimated relationships between bank interest expenses and bank internationalization are statistically significant for the fiscaldeficit sample, but not for the fiscal-surplus sample.

The strength of the financial safety net protecting banks matters more during economic downturns when banks are more likely to become distressed. In line with this, we find that the relationship between a bank's foreign liabilities share and its cost of funds is stronger at times of weak world GDP growth, reflecting higher overall economic and financial risks.

Finally, we acknowledge that a bank's internationalization decision is potentially endogenous to its cost of funds. A bank that is unexpectedly confronted with high interest expenses may, for instance, reduce its degree of internationalization as a way to bring its interest expenses down. Endogeneity of this kind may dampen our estimated effect of bank internationalization on bank interest expenses. To control for this, we apply instrumental variable estimation to our interest expense equations, using indices of country-level international economic integration as instruments for bank-level internationalization. Our instruments relate to tourism, foreign direct investment (FDI), international trade, and international portfolio investment. ${ }^{2}$ As expected, our instrumental variables results show a more positive impact of bank internationalization on bank interest expenses.

Our results suggest that international banks were perceived to have more restricted access to the financial safety net, indicating that banks faced a disincentive to internationalize. This

\footnotetext{
2 This approach is motivated by a literature that explains cross-border banking bilaterally on the basis of FDI, international trade, and other determinants (see Grosse and Goldberg (1991), Brealey and Kaplanis (1996), and Focarelli and Pozzolo (2005)).
} 
implies economic costs, as the degree of bank internationalization would be inefficiently low. However, in a world of inadequate national bank supervision and regulation, and tardy and potentially very costly cross-border resolutions, limited bank internationalization may well have been beneficial. Looking forward, we think that a first priority is to ensure that there is better international coordination of bank regulation and supervision, as well as improved insolvency resolution that ensures cross-border burden sharing. Once this is achieved, safety net reforms to achieve a uniform treatment of domestic and international banks would be the next step.

This paper's findings are consistent with both theoretical and empirical literature on this topic. On a theoretical level, Freixas (2003) models the incentives for national governments to contribute towards the costs of recapitalizing a distressed international bank. Contributing to this cost is an international public good. Underprovision of this public good may result in liquidation of the bank in equilibrium, despite the fact that the aggregate international benefits of recapitalization exceed its cost. The prospect of inefficient bank liquidations of international banks, as modeled by Freixas (2003), could lead to a higher cost of funds for such banks.

Anecdotal evidence from the recent financial crisis also suggests that bank internationalization reduced ex post credit recovery for the bank's liability holders. Claessens et al. (2010, p. 45), in particular, describe how unilateral action of US regulators in the Lehman bankruptcy in 2008 made it almost impossible to salvage much value out of the firm's international operations, implying larger losses to Lehman's liability holders. Furthermore, in 2008 Iceland reneged on the deposit insurance provided to foreign depositors when its banking system collapsed.

A few empirical papers report results that are consistent with a weaker financial safety net for internationalized banks. Ongena and Penas (2009) find that bondholders experience relatively 
low abnormal returns in cross-border bank mergers, possibly reflecting the expectation of a less generous financial safety net treatment of international banks. Furthermore, Beck et al. (2013) find that the CDS spreads of distressed internationalized banks are relatively high at the time of regulatory intervention. This could reflect that the liability holders of international banks expect larger losses at the time of regulatory intervention, consistent with a weaker financial safety net for international banks. Our paper contributes to this emerging literature by providing evidence that greater bank internationalization is associated with higher funding costs reflecting a less generous safety-net access for international banks. ${ }^{3}$

The remainder of this paper is organized as follows. Section 2 discusses the data, and in particular our measures of bank internationalization. Section 3 presents the results on the impact of bank internationalization on banks' funding costs. Section 4 concludes.

\section{The data}

In this paper, we examine an international sample of 903 banks located in 84 countries focusing on the period 1999-2009. Income statement and balance sheet information on individual banks are obtained from the Bankscope database. In addition, Bankscope provides ownership data that we use to match parent banks with directly owned subsidiary banks. ${ }^{4}$ To ensure data quality, we only consider parent banks that are publicly listed.

Of the 903 banks in the sample, around one third have at least one foreign subsidiary. We construct two indices of bank internationalization for parent banks. First, we measure internationalization by the extent to which a bank's liabilities are foreign. Banks with large foreign

\footnotetext{
${ }^{3}$ Previous literature on the market discipline of banks includes Flannery and Sorescu (1996), Sironi (2003), and Demirgüç-Kunt and Huizinga (2004).

${ }^{4}$ Bankscope does not provide information on foreign branches.
} 
liabilities are potentially less likely to receive generous bailout benefits. We focus on bank liabilities, as these are commensurate to the potential size of bank bailouts. The foreign liabilities share variable is constructed as the ratio of the sum of all foreign subsidiaries' liabilities (weighted by the parent bank's ownership share) to the consolidated liabilities of the parent firm. As reported in Table 1, the mean value of the foreign liabilities share is $2.0 \%$ for the sample of all banks, and it is around $5.7 \%$ for the sample of banks that have at least one foreign subsidiary. ${ }^{5}$ Figure 1 plots the distribution of the foreign liabilities share for banks with at least one foreign subsidiary. Among these banks, $55.5 \%$ have a foreign liabilities share of less than $2.5 \%$.

As an alternative internationalization measure, we consider a Herfindahl index of the concentration of the overall bank's liabilities in the countries where the bank operates. A bank with highly concentrated liabilities can expect higher bailout benefits, as there is less of a freerider problem among the countries that potentially need to bail out the bank. The concentration variable is constructed as the sum of the squared shares of a bank's ownership-weighted liabilities (relative to the parent bank's consolidated liabilities) in the countries where it operates. The liability share for the parent country is calculated as 1 minus the liability shares for all foreign countries. The concentration variable reaches a maximum of one for a purely domestic bank. The mean concentration is 0.966 , which reflects that most banks have highly concentrated liabilities primarily in the domestic country. The minimum concentration is 0.271 for a bank with liabilities that are highly dispersed internationally. Figure 2 displays the distribution of the concentration variable. The foreign liabilities share and concentration variables are highly negatively correlated with a correlation coefficient of -0.966 that is significant at $1 \%$.

\footnotetext{
${ }^{5}$ The calculated value of the foreign liabilities share potentially exceeds 1 , as some foreign subsidiaries may have internal debt to the parent bank.
} 
In the empirical work, we examine whether liability internationalization affects a bank's interest expenses. The interest expense variable is constructed as the ratio of interest expenses to total interest-bearing liabilities at the consolidated bank level. ${ }^{6}$ This variable reflects potential stresses at the group level as well as the bank's overall access to the financial safety net in the countries where it operates. The interest expense variable is positively (negatively) correlated with the foreign liabilities share (concentration) variable, consistent with a weaker financial safety net for internationalized banks.

In the presence of strong market discipline, we expect banks with a higher default risk to pay higher interests. Underperforming banks are especially risky. Thus, our main index of failure risk is a bank's profitability rate, constructed as the ratio of pre-tax profits to total assets. Alternatively, we consider a bank's Z-score constructed as the sum of a bank's return on assets and its capital-to-assets ratio, divided by the standard deviation of the return on assets (and by the $\log$ of total assets to normalize for bank size). In addition, we consider an index of bank asset risk. Specifically, bank asset volatility is the delevered standard deviation of bank stock returns, or more precisely the annualized standard deviation of bank stock returns multiplied by the ratio of the market value of common equity to the imputed market value of assets (see Nikolova, 2003).

The empirical work includes several bank-level and country-level control variables. Banks that are large may face lower interest expenses on account of being too-big-to-fail (TBTF), or alternatively pay higher interest rates if they are too-big-to-save (TBTS). To control for a bank's absolute size, we include the assets variable, constructed as the log of total bank assets. Alternatively, the TBTF variable is a dummy variable that equals one if a bank's liabilities are larger than the $90^{\text {th }}$ percentile of the sample. To reflect a bank's size relative to the national

\footnotetext{
${ }^{6}$ Our data source does not allow us to split interest expenses into interest paid on deposits and on other liabilities.
} 
economy, we construct the TBTS variable as a dummy variable that equals one if the ratio of a bank's liabilities to GDP exceeds the $90^{\text {th }}$ percentile (or a liabilities-to-GDP ratio of $30.4 \%$ ). ${ }^{7}$

The overhead variable is constructed as the ratio of personnel and other non-interest expenses to total assets. Several additional variables reflect a bank's funding strategy. The shortterm debt variable is computed as short-term debt divided by total interest-bearing liabilities. The tier1 capital ratio, computed as tier1 capital relative to risk-weighted assets. The deposit funding variable is the share of deposits in total liabilities. Deposit funding may lead to lower funding costs, as deposits tend to be protected by deposit insurance.

Macroeconomic control variables are the parent country's consumer price inflation, growth rate of real GDP per capita, and GDP per capita in thousands of constant 2000 US dollars. A bank's average worldwide funding costs can be expected to reflect inflation in the parent country as well as in other countries where the bank operates to the extent that it attracts funding in these other countries. To reflect this, we construct the inflation difference variable as the average foreign inflation rate weighted by the bank's country-level foreign liabilities minus the inflation rate in the parent country.

Finally, there are four indices of country-level economic integration that we use as instruments for bank-level internationalization. First, tourism is the total number of tourist arrivals in and departures from a country normalized by its population. Second, FDI stands for foreign direct investments flows, both inward and outward, relative to GDP. Third, openness is the sum of exports and imports over GDP. Fourth, portfolio position stands for the stocks of inward and outward portfolio investments of a country divided by its GDP.

\footnotetext{
${ }^{7}$ Demirgüç-Kunt and Huizinga (2013) find that a bank's market-to-book value is negatively related to the size of its liabilities-to-GDP ratio, which suggests that banks with large liabilities relative to GDP can be too large to save.
} 


\section{Empirical results on bank internationalization and interest expenses}

\subsection{Basic empirical results}

Empirically, we relate a bank's interest expenses to its foreign liabilities share, or to its foreign liability concentration, as alternative indices of bank internationalization. The basic estimating relationship between interest expenses and the bank's foreign liabilities share is as follows:

$$
\begin{aligned}
& \text { Interest expense } e_{i j t}=\alpha_{i}+\gamma_{t}+\beta_{1} \text { Foreign liabilities share } i j t+ \\
& \beta_{2} \text { Profit }_{i j t-1} * \text { Foreign liabilities share } i j t+\beta_{3} \text { Bank }_{i j t}+\beta_{4} \text { Country }_{j t}+\varepsilon_{i j t}
\end{aligned}
$$

where the subscripts $i, j$, and $t$ denote the bank, the country, and the year, and $\alpha_{i}$ and $\gamma_{t}$ are bank and year fixed effects. Further, Bank $k_{i j t}$ is a set of bank variables including lagged bank profitability, and Country $y_{j t}$ is a set of macroeconomic variables.

The coefficient $\beta_{1}$ reflects the effect of the foreign liabilities share on interest expenses. We expect a negative sign on the coefficient $\beta_{1}$ since a high foreign liabilities share potentially reduces a bank's access to the financial safety net, increasing its default risk, and therefore also its interest expenses. The coefficient $\beta_{2}$ captures whether the relationship between interest expenses and a bank's foreign liabilities share depends on its performance, as proxied by the lagged bank profitability variable. A negative estimated coefficient $\beta_{2}$ would indicate that bank interest expenses rise relatively more with the foreign liabilities share for underperforming banks. Banks with low profitability stand a greater chance of bank distress and are more likely to access the financial safety net. Hence, a negative value of $\beta_{2}$ is consistent with the view that the estimated relationship between bank interest expenses and the foreign liabilities share reflects the ability of the banks to rely on the financial safety net. In a robustness check, we replace the bank's profit 
variable by the growth rate of world GDP per capita to proxy for general economic and financial conditions.

Table 2 reports interest expense regressions including either the foreign liabilities share or concentration as an index of bank liability internationalization. The regressions include bank and year fixed effects, and robust standard errors are reported. Regression 1 includes the foreign liabilities share without its interaction with profitability. The estimated coefficient for the foreign liabilities share is positive at 0.021 and significant at 5\%. Regression 2 adds the interaction of the foreign liabilities share and profitability variables, yielding positive and negative coefficients for the foreign liabilities share variable and its interaction with profitability that are significant at $5 \%$ and $10 \%$, respectively. These results suggest that interest expenses rise with the foreign liabilities share, and especially for banks with low profitability. This evidence is consistent with the notion that international banks, and especially underperforming ones, rely less on the financial safety net.

In regressions 3 and 4 we substitute the concentration variable for the foreign liabilities share in regressions 1 and 2 . In both regressions, the concentration variable obtains a negative and significant coefficient, while the interaction of the concentration and profitability variables obtains a positive and significant coefficient in regression 4 . This is again consistent with a reduced access to the financial safety net for internationalized banks, especially if they are underperforming. ${ }^{8}$

In regressions 5-8, we add several bank-level control variables to the earlier specifications 1-4. The additional control variables are: lagged asset volatility as an index of bank asset risk, the lagged tier1 ratio as a regulatory capital ratio, and deposit funding to represent the extent of bank

\footnotetext{
${ }^{8}$ In a robustness check, we adjust the interest expense variable for the 3 -months interbank interest rate available from the OECD. In unreported regressions analogous to regressions 1-4 of Table 2, the foreign liabilities share (concentration) variables obtain positive (negative) coefficients that are statistically significant, but the interactions of these variables with the profit variable are no longer significant.
} 
funding obtained through deposits. The lagged tier1 ratio enters these regressions with negative and significant coefficients, which suggest that better capitalized banks have lower funding costs. Notably, we find that our results indicating a diminished strength of the financial safety net for internationalized banks are robust to including a larger set of control variables.

In summary, the results in Table 2 suggest that internationalized banks have significantly higher interest costs. In addition, there is evidence that underperforming international banks face even higher interest expenses, consistent with a greater probability that these banks need to access the financial safety net.

\subsection{Robustness checks}

This subsection presents the results of several robustness checks. To start, regressions 1 and 2 of Table 3 add the inflation difference variable interacted with the foreign liabilities share variable to regressions 1 and 2 of Table 2 to control for the potentially different inflationary environment that an international bank faces abroad. We expect this interaction variable to obtain positive coefficients as higher inflation abroad may result in higher foreign nominal interest rates. Indeed, in regressions 1 and 2 the Inflation difference ${ }^{*}$ Foreign liabilities share variable obtains positive and significant coefficients. Importantly, controlling for this effect does not change the main results significantly.

The estimated coefficients of regression 2 in Table 3 can be used to evaluate the economic significance of the estimated relationship between a bank's interest expense ratio and its foreign liabilities share. A one standard deviation increase in the foreign liabilities share of 0.068 (evaluated at a mean profitability of 0.013 , and a mean inflation difference of -0.007 from Table 1) is estimated to increase the interest expense ratio by 0.0008 or $0.08 \%[=(0.026+(-$ $0.875 * 0.013)+(0.400 *(-0.007))) * 0.068]$. This is equivalent to a share of $0.0008 / 0.024$, or $3.3 \%$, of 
the standard deviation of the interest variable, which is 0.024 from Table 1 . Thus, variation in the foreign liabilities share can explain only a small part of the variation in bank interest expenses. This is not surprising, as most banks in the sample are purely domestic and even most international banks have predominantly domestic liabilities.

Perhaps a more meaningful way to assess the impact of liability internationalization on interest costs is to compare the cost of funds for an internationalized bank to the domestic cost of funds for a similar, purely domestic bank. In the odd numbered regressions in Tables 2 and 3, we obtain significant coefficients for the linear foreign liabilities share variable that range from 0.012 to 0.021 . This suggests that the (marginal) cost of foreign liabilities is between $1.2 \%$ and $2.1 \%$ higher than the cost of funds for a purely domestic bank, which is a material difference given an overall mean interest expense of $3.3 \%$ from Table 1.

By implication, the interest expense ratio is estimated to be between 7 and 12 basis points higher for the average internationalized bank with a foreign liabilities share of $5.7 \%$ compared to a purely domestic bank. Using ratings information, Ueda and di Mauro (2010) previously estimated that banks in G20 countries and in Spain and Switzerland received interest subsidies from the financial safety net in the range of $10-50$ basis points in 2007 . These various estimates together suggest that banks around the world receive a net subsidy from the financial safety net even if this subsidy is lower for international banks.

Next, regressions 3 and 4 of Table 3 include the TBTF and TBTS variables as additional measures of a bank's absolute size and its size relative to GDP to proxy for a bank's potential toobig-to-fail or too-big-to-save status. The TBTF variable receives positive but insignificant coefficients, while the TBTS variable is estimated with positive and significant coefficients in both regressions. The latter results suggest that banks that are large relative to their national economies 
may be too large to save. In these regressions, estimated coefficients for the foreign liabilities share and its interaction with lagged profit are very similar to those in regressions 1 and 2.

In regressions 5 and 6 , we replace the lagged profit variable as a proxy for bank risk by the Z-score, yielding coefficients for the foreign liabilities share that are largely unchanged. ${ }^{9}$ The Zscore variable and its interaction with the foreign liabilities share variable obtain insignificant coefficients, perhaps reflecting the reduced sample size. Overall, the results in Table 3 confirm a positive estimated relationship between the foreign liabilities share and the interest expense ratio.

Next, we investigate the plausibility of the financial safety net explanation by examining how the relationship between bank interest expenses and liability internationalization depends on the fiscal strength of the bank's parent country. Fiscal problems may raise doubts on the government's capacity and willingness to carry out expensive international bank bailouts, particularly for international banks. Therefore, bank interest expenses are expected to vary positively with bank liability internationalization especially in countries that run central government fiscal deficits. To check this, columns 1 and 2 of Table 4 report the results of interest expense regressions including either the foreign liabilities share or the concentration variables for the sample of only fiscal-surplus observations, while columns 3 and 4 show the results of analogous regressions for only fiscal-deficit observations. For the fiscal-surplus sample, the foreign liabilities share variable in regression 1 and the concentration variable in regression 2 obtain coefficients that are statistically insignificant. Alternatively, for the fiscal-deficit sample the corresponding estimated coefficients are 0.032 and significant at $1 \%$ in regression 3 , and -0.026 and significant at $1 \%$ in regression 4. Moreover, these estimated coefficients are larger in absolute

\footnotetext{
${ }^{9}$ Similar results are obtained if we use the standard deviation of the return on equity as a bank risk variable (unreported).
} 
value than the corresponding estimates in regression 1 of Table 3 and regression 3 of Table 2 . These results suggest that the relationships between funding costs and measures of internationalization are stronger for banks from fiscal-deficit countries than for the overall sample. Notably, there is no such relationship for fiscal-surplus countries' banks. This is evidence that the empirical relationship between interest expenses and bank liability internationalization reflects a reduced ability to rely on the financial safety net for internationalized banks.

Finally, we test whether the relationship between a bank's overall interest expenses and its foreign liabilities share depends on the world business cycle. We include an interaction variable of the foreign liabilities share with the growth rate of world GDP per capita - replacing the interaction of the foreign liabilities share with lagged profit. The results are reported as regressions 5 and 6 in Table 4 for the full sample and for the sample excluding outliers where the foreign liabilities share exceeds 0.3 (as seen in Figure 1), respectively. The included interaction term is negative in both regressions, but statistically significant (at 5\%) only in regression 6 . The negative estimated coefficient for the interaction term in regression 6 indicates that internationalized banks face higher interest expenses especially at times of slow world economic growth. This suggests that the liabilities of international banks are considered relatively risky at times of economic and financial downturns confirming the view that international banks expect to rely less on the financial safety net.

\subsection{Endogeneity issues}

Our results so far suggest that bank internationalization leads to higher interest expenses. This implies that an international bank confronted with high interest expenses may reduce these by lowering its degree of internationalization. Thus, higher interest expenses may trigger a reduction in internationalization, making internationalization endogenous to interest expenses. 
Endogeneity of this kind may lead to a downward bias (in absolute terms) of the estimated impact of our internationalization measures on interest expenses. To address this endogeneity, we estimate IV regressions where we use indices of international economic integration at the country level to instrument for bank-level internationalization. Measures of country-level economic integration should be positively correlated with measures of bank-level internationalization, but they are unlikely to be affected by the level of bank interest expenses. Hence, they are likely to be appropriate instruments.

As instruments, we use four measures of country-level international economic integration: the number of tourist arrivals and departures over total population, the sum of inward and outward FDI over GDP, exports plus imports over GDP, and the sum of portfolio-investment assets and liabilities over GDP. In the estimation, we use a bank fixed-effects model with two-step GMM estimation with robust standard errors. All the instruments are expected to have a positive (negative) impact on the foreign liabilities share (the foreign liability concentration), as banks in internationally integrated economies should internationalize their funding more (and concentrate it less). The estimated coefficients from the first-stage regressions provided in Table 5 tend to confirm this expectation, as the instruments generally obtain positive signs in the first-stage foreign liabilities share regressions 1 and 2 (and negative signs in the concentration regressions 3 and 4). Tourism as an instrument is significant in all 4 first-stage regressions in Table 5, while FDI is significant in regressions 1 and 3 that do not include an interaction term of the included internationalization variable and profit. The joint significance tests for excluded instruments are rejected for all regressions at least at the $5 \%$ level, with p-values presented in the table. The firststage regressions for the interaction terms of an internationalization variable with profit also perform well (not reported). Underidentification does not seem to be a problem, as all regressions 
in the table pass underidentification tests with at least $10 \%$ significance - except the last regression with a p-value 0.11 .

Our instruments reflect country-level economic integration, and there is no obvious reason why they should affect bank-level interest expenses other than through bank-level internationalization. Indeed, our instruments do not significantly affect interest expenses when included in baseline regressions. We report the results of overidentifying restrictions tests in the form of Hansen J-tests for our efficient GMM estimation. The results indicate that the overidentifying restrictions tests are met in all regressions.

In the second-stage interest expense regressions 1 and 2, the foreign liabilities share is estimated with coefficients of 0.094 and 0.155 that are significant at the $5 \%$ level. These estimated coefficients are higher than the corresponding coefficients in Table 3, which suggest a downward bias in our earlier estimation. In regression 3, the concentration variable enters with a negative coefficient of -0.082 that is significant at $1 \%$, and more negative than the analogous estimate in regression 3 of Table 2 confirming downward bias in the OLS estimation. Coefficients for the interactions of the included internationalization variable and profit are estimated to be statistically insignificant in Table 5. Overall, the IV estimation in Table 5 confirms our results that bank internationalization causes higher bank interest expenses, consistent with the perception of a more fragile financial safety net for internationalized banks.

\subsection{The global financial crisis and the post-crisis period}

In this subsection, we examine whether the relationship between interest expenses and bank internationalization was different during the crisis years 2007-2009, and during the post-crisis period 2010-2013. 
To see whether perceptions of financial safety net strength were different during the crisis, we add interactions of a crisis dummy variable representing the years 2007-2009 with all righthand-side variable to regressions 1-4 of Table 2. The results are reported in Table 6. In regression 4, only the concentration variable and its interaction with the crisis variable obtain negative and significant coefficients, suggesting that liability concentration gave rise to lower interest expenses especially during the crisis. In the table, all other double and triple interactions terms involving crisis and either foreign liabilities share or concentration are statistically insignificant, while the foreign liabilities share and concentration measures themselves are significant (except in regressions 3 and 5). Overall, these results suggest that the relationship between bank liability internationalization and interest expenses was not significantly changed during the global financial crisis.

During the crisis, many countries provided extensive public support to domestic as well as internationally active banks. As a result, the experience of the crisis may have strengthened perceptions of the relative reliability of the financial safety net available to international banks compared to domestic banks. In addition, the more recent period was characterized by the Eurozone sovereign debt crisis of 2010-2012 which triggered extraordinary policy responses from the European Central Bank. These events may have changed the internationalization-interest expense relationship we observed before the crisis.

To examine this, we re-estimate regressions 1-4 of Table 2 for a sample that includes the post-crisis years 2010-2013, and report the results as regressions 1-4 in Table 7. For the extended sample, coefficients for the included internationalization variables and their interactions with profitability are statistically significant with the exception of the concentration variable in regression 3. Estimated coefficients tend to be smaller in absolute value than in Table 2. In 
specifications 5-8 we add interactions of a post-crisis dummy variable with bank internationalization variables. The signs of the coefficients for the interactions of internationalization variables with the post-crisis dummy tend to be consistent with a weaker relationship between internationalization and interest expenses in the post-crisis period, but these coefficients are statistically insignificant. Overall, the results of Table 7 are suggestive evidence that the crisis may have strengthened the perception of the reliability of the financial safety net applicable to internationally active banks relative to domestic banks.

\section{Conclusion}

This paper provides evidence that internationalized banks face higher interest expenses. In particular, banks with a higher share of foreign liabilities and a lower international concentration of their liabilities pay higher interest on their liabilities. We provide several pieces of evidence suggesting that internationalized banks faced higher interest expenses reflecting a more restricted access to the financial safety net.

First, the estimated relationships between bank interest expenses on the one hand and the foreign liabilities share and the international liabilities concentration on the other are attenuated for highly profitable banks, which are less likely to require access to the financial safety net. Second, the empirical relationships between bank interest expenses and our measures of bank internationalization are significant only if the country where the parent bank is located is experiencing a fiscal deficit, casting some doubt on the country's ability and willingness to provide generous bailout support to its banking system when needed. Third, the interest expense premium that international banks pay relative to purely domestic banks is highest at times of weak world GDP growth as a proxy for overall economic and financial risks. Finally, our finding that 
internationalized banks face higher interest expenses is robust to IV estimation where we use indices of country-level economic integration to instrument for bank-level internationalization.

Having a more restricted access to the financial safety net with internationalization may have discouraged banks from becoming more international. This has the disadvantage that the potential economic benefits of international banking market integration are less likely to be reaped. However, the model of international banking pursued before the global financial crisis was deeply flawed in the sense that the institutional infrastructure for international banking was largely incomplete. Specifically, regulation and supervision and the treatment and resolution of weak banks were not coordinated, and burden sharing rules in cases of international bank failures were unclear. In the absence of adequate international policy integration, having a safety net that extends to international activities can actually backfire since it can be a recipe for excessive risk-taking and moral hazard. Hence despite its efficiency costs, a more limited safety net for international banks may have been appropriate during this period because of its potential stability benefits. More uniform access to the financial safety net for domestic and international banks would make sense if the two types of banks also receive equal treatment by bank supervisors, and in recovery and resolution proceedings.

One way to bring about equal treatment is to transfer supervisory and resolution powers to an international or supranational level. This has to a large extent occurred in Europe where bank supervisory powers have recently been transferred to the European Central Bank as the single supervisor in the Eurozone, and where the Single Resolution Board has the task of developing resolution plans for failing EU banks. We already observe weak evidence that safety net access may have become more equal for international banks in the post-crisis period. In future empirical 
work, it will be possible to determine whether these institutional changes have indeed contributed to a more uniform access to the financial safety net for domestic and international banks. 


\section{References}

Beck, Thorsten, Radomir Todorov, and Wolf Wagner, 2013, Supervising cross-border banks: Theory, evidence and policy, Economic Policy, 5-44.

Brealey, Richard A, and Evi C. Kaplanis, 1996, The determination of foreign banking location, Journal of International Money and Finance 15, 577-597.

Claessens, Stijn, Richard Herring, Dirk Schoenmaker, and Kimberley Summe, 2010, A safer world financial system: Improving the resolution of systemic institutions, Geneva Report on the World Economy 12.

Demirgüç-Kunt, Asli, and Harry Huizinga, 2004, Market discipline and deposit insurance, Journal of Monetary Economics 51, 375-399.

Demirgüç-Kunt, Asli, and Harry Huizinga, 2013, Are banks too big to fail or too big to save? International evidence from equity prices and CDS spreads, Journal of Banking and Finance 37, 875-894.

Flannery, Mark J. and Sorin M. Sorescu, 1996, Evidence of bank market discipline in subordinated debenture yields: 1983-1991, Journal of Finance 51, 1347-1377.

Focarelli, Dari, and Alberto Pozzolo, 2005, Where do banks expand abroad? An empirical analysis, Journal of Business 78, 2435-2464.

Freixas, Xavier, 2003, Crisis management in Europe, in Financial supervision in Europe, Jeroen Kremers, Dirk Schoenmaker and Peter Wierts (eds.), 102-119, Edward Elgar, Cheltenham.

Grosse, Robert, and Lawrence Goldberg, 1991, Foreign bank activity in the United States: An analysis by country of origin, Journal of Banking and Finance 15, 1093-1112.

Nikolova, Stanislava M., 2003, The informational content and accuracy of implied asset volatility as a measure of total firm risk, University of Florida Working Paper No. 8.

Ongena, Steven and Maria Fabiana Penas, 2009, Bondholders' wealth effects in domestic and cross-border bank mergers, Journal of Financial Stability 5, 256-271.

Sironi, Andrea, 2003, Testing for market discipline in the European banking industry: Evidence from subordinated debt issues, Journal of Money, Credit, and Banking 35, 443-472.

Ueda, Kenichi and Beatrice Weder di Mauro, 2010, The value of the too-big-to-fail subsidy to financial institutions, in: Stijn Claessens, Michael Keen und Ceyla Pazarbasioglu (eds.), Financial Sector Taxation: The IMF's Report to the G-20 and Background Material. 


\section{Appendix}

Table A1. Variable definitions and data sources

\begin{tabular}{l} 
Variable \\
\hline Foreign liabilities \\
Concentration \\
Interest expense \\
Lagged profit \\
Lagged Z-score
\end{tabular}

Lagged Z-score

Lagged asset volatility

Assets

TBTF

TBTS

Overhead

Short-term debt

Lagged tier1 ratio

Deposit funding

Inflation

GDP growth

World GDP growth

GDP per capita

Inflation difference

\section{Tourism \\ FDI}

Openness
Sum of the liabilities of foreign subsidiary ba
by the parent bank's consolidated liabilities

Sum of the squared shares of bank liabilities weighted by the parent bank's ownership in a country relative to the parent's bank consolidated liabilities for all countries where the parent bank operates

Interest expense over bank liabilities excluding non-interest bearing debt

Pre-tax profits divided by assets, lagged one period

Index of bank solvency constructed as (ROA+CAR)/stddev(ROA), where ROA is return on assets, CAR

is ratio of capital to assets, and stddev(ROA) is the standard deviation of return on assets. It is calculated

for 4-years rolling windows, normalized by total assets, and lagged one period

Bank asset volatility calculated as $\operatorname{stddev}(\mathrm{R}) *(\mathrm{E} / \mathrm{V})$, where $\operatorname{stddev}(\mathrm{R})$ is the annualized standard deviation of weekly dividend-inclusive bank stock returns, $\mathrm{E}$ is the market value of common equity and $\mathrm{V}$ is the book value of assets plus the market value of common equity minus the book value of common equity, lagged one period

Log of assets in millions of 2000 US dollars

Dummy variable that equals one if a bank's liabilities in 2000 US dollars are larger than the $90^{\text {th }}$

percentile of the sample

Dummy variable that equals one if a bank's liabilities over GDP is larger than the $90^{\text {th }}$ percentile of the sample

Ratio of personnel and other non-interest expenses to assets

Customer and short-term funding to total interest paying debt

Share of tier1 capital in risk weighted assets and off balance sheet risks as measured under Basel rules, lagged one period

Share of deposit funding in total liabilities.

Rate of change in consumer prices

Rate of real per capita GDP growth

Rate of real per capita GDP growth at global level

GDP per capita in thousands of constant 2000 U.S. dollars

Difference between foreign inflation and parent-country inflation where foreign inflation is the sum of foreign-country inflation rates weighted by the foreign countries' shares in total foreign liabilities of a parent bank

Sum of number of tourist arrivals and departures over population of the country

Sum of inward and outward flows of foreign direct investments over GDP

Sum of exports and imports over GDP
Sources

Bankscope

Bankscope

Bankscope

Bankscope

Bankscope

Bankscope and

Datastream

Bankscope and WDI

Bankscope

Bankscope and WDI

Bankscope

Bankscope

Bankscope

WDI

WDI

WDI

WDI

Bankscope and WDI

WDI

WDI

WDI 
Portfolio position

Fiscal balance

Crisis

Post-crisis
Sum of assets and liabilities with respect to a country's portfolio investment position over GDP Net operating balance calculated as revenues minus expenses of general government over GDP

Dummy variable that equals 1 for the years 2007-2009

Dummy variable that equals 1 for the years 2010-2013
IMF IFS

IMF GFS 
Table 1. Summary statistics on internationalization and other variables for the period 1999-2009

Foreign liabilities share is the sum of the liabilities of foreign subsidiary banks weighted by the parent bank's ownership share divided by the parent bank's consolidated liabilities Concentration is the sum of the squared shares of bank liabilities weighted by the parent bank's ownership in a country relative to the parent's bank consolidated liabilities for all countries where the parent bank operates. Interest expense is interest expense over bank liabilities excluding non-interest bearing debt. Lagged profit is pre-tax profits divided by total assets, lagged one period. Lagged Z-score is index of bank solvency constructed as (ROA+CAR)/stddev(ROA), where ROA is return on assets, CAR is ratio of capital to assets, and stddev(ROA) is the standard deviation of return on assets. It is calculated for 4-years rolling windows, normalized by total assets, and lagged one period. Lagged asset volatility is calculated as $\operatorname{stddev}(\mathrm{R}) *(\mathrm{E} / \mathrm{V})$, where stddev $(\mathrm{R})$ is annualized standard deviation of weekly dividend-inclusive bank stock returns, $\mathrm{E}$ is market value of common equity and $\mathrm{V}$ is book value of assets plus market value of common equity minus book value of common equity, lagged one period. Assets is the natural logarithm of total assets in constant 2000 US dollars. TBTF is a dummy variable that equals 1 if a bank's assets in 2000 US dollars are larger than the $90^{\text {th }}$ percentile of the sample. TBTS is a dummy variable that equals 1 if a bank's liabilities over GDP is larger than the $90^{\text {th }}$ percentile of the sample. Overhead is personnel expenses and other non-interest expenses over total assets. Short-term debt is customer and short-term funding over total interest paying debt. Lagged tierl ratio is the share of tierl capital in risk weighted assets and off balance sheet risks measured under the Basel rules, lagged one period. Deposit funding is the share of deposit funding in total liabilities. Inflation is the rate of change in consumer prices. GDP growth is the rate of real per capita GDP growth. World GDP growth is the rate of real per capita GDP growth at global level. GDP per capita is GDP per capita in thousands of constant 2000 dollars. Inflation difference is the difference between foreign inflation and parent-country inflation where foreign inflation is the sum of foreign-country inflation rates weighted by the foreign countries' shares in total foreign liabilities of a parent bank. Tourism is total number of tourist arrivals and departures over total population. FDI is the sum of inward and outward flows of foreign direct investments over GDP. Openness is the sum of exports and imports of goods and services over GDP. Portfolio position is the sum of assets and liabilities regarding a country's portfolio investment position over GDP.

\begin{tabular}{|c|c|c|c|c|c|}
\hline Variables & Obs. & Mean & Std. dev. & Min & Max \\
\hline Foreign liabilities share & 3727 & 0.020 & 0.068 & 0 & 1.640 \\
\hline Concentration & 3725 & 0.966 & 0.090 & 0.271 & 1 \\
\hline Interest expense & 3727 & 0.033 & 0.024 & 0.000 & 0.289 \\
\hline Lagged profit & 3727 & 0.013 & 0.024 & -0.437 & 0.293 \\
\hline Lagged Z-score & 1477 & 1.462 & 1.321 & 0.007 & 6.516 \\
\hline Lagged asset volatility & 2163 & 0.035 & 0.035 & 0.000 & 0.613 \\
\hline Assets & 3727 & 22.935 & 2.221 & 17.540 & 28.788 \\
\hline TBTF & 3727 & 0.102 & 0.303 & 0 & 1 \\
\hline TBTS & 3727 & 0.106 & 0.308 & 0 & 1 \\
\hline Overhead & 3727 & 0.028 & 0.019 & 0.002 & 0.200 \\
\hline Short-term debt & 3727 & 0.814 & 0.171 & 0 & 0.995 \\
\hline Lagged tier1 ratio & 2163 & 0.106 & 0.041 & 0.005 & 0.492 \\
\hline Deposits funding & 3717 & 0.755 & 0.185 & 0 & 0.995 \\
\hline Inflation & 3727 & 0.037 & 0.056 & -0.040 & 0.961 \\
\hline GDP growth & 3727 & 0.021 & 0.030 & -0.210 & 0.433 \\
\hline World GDP growth & 3727 & 0.012 & 0.020 & -0.034 & 0.028 \\
\hline GDP per capita & 3727 & 24.983 & 14.583 & 0.154 & 63.475 \\
\hline Inflation difference & 1310 & -0.007 & 0.083 & -0.961 & 0.451 \\
\hline Tourism & 3096 & 0.797 & 1.380 & 0.008 & 14.221 \\
\hline Openness & 3096 & 0.542 & 0.539 & 0.190 & 4.381 \\
\hline Portfolio position & 3096 & 1.002 & 0.717 & 0.000 & 15.126 \\
\hline
\end{tabular}


Table 2. A bank's interest expense and its foreign liabilities

The dependent variable is Interest expense, which is interest expense over bank liabilities excluding non-interest bearing debt. Assets is the natural logarithm of total assets in constant 2000 US dollars. Lagged profit is pre-tax profits divided by total assets, lagged one period. Overhead is personnel expenses and other non-interest expenses over total assets. Short-term debt is ratio of customer and short-term funding over total interest paying debt. Inflation is rate of change in consumer prices. GDP growth is rate of real per capita GDP growth. GDP per capita is GDP per capita in thousands of constant 2000 dollars. Foreign liabilities share is the sum of the liabilities of foreign subsidiary banks weighted by the parent bank's ownership share divided by the parent bank's consolidated liabilities. Concentration is the sum of the squared shares of bank liabilities weighted by the parent bank's ownership in a country relative to the parent's bank consolidated liabilities for all countries where the parent bank operates. Lagged asset volatility is calculated as $\operatorname{stddev}(\mathrm{R}) *(\mathrm{E} / \mathrm{V})$, where stddev $(\mathrm{R})$ is annualized standard deviation of weekly dividend-inclusive bank stock returns, E is market value of common equity and $\mathrm{V}$ is book value of assets plus market value of common equity minus book value of common equity, lagged one period. Lagged tierl ratio is share of tier1 capital in risk weighted assets and off balance sheet risks as measured under Basel rules, lagged one period. Deposit funding is share of deposits in total liabilities. Bank and year fixed effects are included. Sample period is 1999-2009. Robust standard errors are given in parentheses. *,** and *** denote significance at $10 \%, 5 \%$ and $1 \%$.

\begin{tabular}{|c|c|c|c|c|c|c|c|c|}
\hline & (1) & (2) & (3) & (4) & (5) & (6) & (7) & (8) \\
\hline \multirow[t]{2}{*}{ Assets } & 0.001 & 0.001 & 0.001 & 0.001 & 0.002 & 0.002 & 0.002 & 0.002 \\
\hline & $(0.002)$ & $(0.002)$ & $(0.002)$ & $(0.002)$ & $(0.002)$ & $(0.002)$ & $(0.002)$ & $(0.002)$ \\
\hline \multirow[t]{2}{*}{ Lagged profit } & $-0.075^{*}$ & -0.057 & $-0.076^{*}$ & $-0.939 *$ & $-0.038^{*}$ & -0.034 & $-0.037^{*}$ & $-0.924^{* *}$ \\
\hline & $(0.039)$ & $(0.043)$ & $(0.039)$ & $(0.512)$ & $(0.021)$ & $(0.021)$ & $(0.021)$ & $(0.456)$ \\
\hline \multirow[t]{2}{*}{ Overhead } & $0.265 * * *$ & $0.267 * * *$ & $0.266 * * *$ & $0.268 * * *$ & $0.070 *$ & $0.074 * *$ & $0.070 *$ & $0.074 * *$ \\
\hline & $(0.093)$ & $(0.092)$ & $(0.094)$ & $(0.094)$ & $(0.037)$ & $(0.037)$ & $(0.037)$ & $(0.037)$ \\
\hline Short-term debt & -0.001 & 0.000 & -0.002 & 0.000 & 0.008 & 0.008 & 0.007 & 0.008 \\
\hline Inflation & $\begin{array}{c}0.079 * * * \\
(0.020)\end{array}$ & $\begin{array}{c}0.078 * * * * \\
(0.020)\end{array}$ & $\begin{array}{c}0.079 * * * \\
(0.020)\end{array}$ & $\begin{array}{c}0.078 * * * \\
(0.020)\end{array}$ & $\begin{array}{c}0.163 * * * \\
(0.032)\end{array}$ & $\begin{array}{c}0.164 * * * \\
(0.032)\end{array}$ & $\begin{array}{c}0.162 * * * \\
(0.032)\end{array}$ & $\begin{array}{c}0.163 * * * * \\
(0.032)\end{array}$ \\
\hline GDP growth & $\begin{array}{c}-0.045^{* * *} \\
(0.022)\end{array}$ & $\begin{array}{c}-0.046^{* * *} \\
(0.021)\end{array}$ & $\begin{array}{c}-0.046^{* * *} \\
(0.022)\end{array}$ & $\begin{array}{c}-0.046^{* * *} \\
(0.021)\end{array}$ & $\begin{array}{l}-0.029 \\
(0.025)\end{array}$ & $\begin{array}{l}-0.028 \\
(0.024)\end{array}$ & $\begin{array}{l}-0.029 \\
(0.025)\end{array}$ & $\begin{array}{l}-0.028 \\
(0.024)\end{array}$ \\
\hline GDP per capita & $\begin{array}{c}0.000 \\
(0.000)\end{array}$ & $\begin{array}{c}0.000 \\
(0.000)\end{array}$ & $\begin{array}{c}0.000 \\
(0.000)\end{array}$ & $\begin{array}{c}0.000 \\
(0.000)\end{array}$ & $\begin{array}{c}-0.000^{* * * *} *{ }^{2} \\
(0.000)\end{array}$ & $\begin{array}{c}-0.000 * * * \\
(0.000)\end{array}$ & $\begin{array}{c}-0.000 * * * \\
(0.000)\end{array}$ & $\begin{array}{c}-0.000 * * * * \\
(0.000)\end{array}$ \\
\hline Foreign liabilities share & $\begin{array}{c}0.021 * * \\
(0.009)\end{array}$ & $\begin{array}{c}0.042 * * \\
(0.021)\end{array}$ & & & $\begin{array}{c}0.012^{* *} \\
(0.005)\end{array}$ & $\begin{array}{c}0.023 * * * \\
(0.007)\end{array}$ & & \\
\hline Lagged profit*Foreign liabilities share & & $\begin{array}{l}-1.740 * \\
(1.045)\end{array}$ & & & & $\begin{array}{l}-1.274^{*} \\
(0.766)\end{array}$ & & \\
\hline Concentration & & & $\begin{array}{c}-0.009^{* *} \\
(0.004)\end{array}$ & $\begin{array}{c}-0.021^{* *} \\
(0.009)\end{array}$ & & & $\begin{array}{c}-0.010^{* * * *} \\
(0.003)\end{array}$ & $\begin{array}{c}-0.019^{* * * *} \\
(0.005)\end{array}$ \\
\hline Lagged profit $*$ Concentration & & & & $\begin{array}{l}0.882 * \\
(0.529)\end{array}$ & & & & $\begin{array}{l}0.892 * \\
(0.457)\end{array}$ \\
\hline Lagged asset volatility & & & & & $\begin{array}{l}-0.001 \\
(0.008)\end{array}$ & $\begin{array}{l}-0.001 \\
(0.008)\end{array}$ & $\begin{array}{l}-0.001 \\
(0.008)\end{array}$ & $\begin{array}{l}-0.001 \\
(0.008)\end{array}$ \\
\hline Lagged tier1 ratio & & & & & $\begin{array}{c}-0.054 * * \\
(0.026)\end{array}$ & $\begin{array}{c}-0.055^{* * *} \\
(0.026)\end{array}$ & $\begin{array}{c}-0.054^{* *} * \\
(0.026)\end{array}$ & $\begin{array}{c}-0.055^{* * *} \\
(0.026)\end{array}$ \\
\hline Deposit funding & & & & & $\begin{array}{c}0.006 \\
(0.007)\end{array}$ & $\begin{array}{c}0.006 \\
(0.007)\end{array}$ & $\begin{array}{c}0.006 \\
(0.007)\end{array}$ & $\begin{array}{c}0.006 \\
(0.007)\end{array}$ \\
\hline $\mathrm{N}$ & 3727 & 3727 & 3725 & 3725 & 2023 & 2023 & 2023 & 2023 \\
\hline R-sq & 0.353 & 0.360 & 0.351 & 0.357 & 0.438 & 0.440 & 0.440 & 0.442 \\
\hline
\end{tabular}




\section{Table 3. Robustness checks for interest expense regressions}

The dependent variable is Interest expense, which is interest expense over bank liabilities excluding non-interest bearing debt. Assets is the natural logarithm of total assets in constant 2000 US dollars. Lagged profit is pre-tax profits divided by total assets, lagged one period. Overhead is personnel expenses and other non-interest expenses over total assets. Short-term debt is ratio of customer and short-term funding to total interest paying debt. Inflation is rate of change in consumer prices. GDP growth is rate of real per capita GDP growth. GDP per capita is GDP per capita in thousands of constant 2000 dollars. These control variables are included in the regressions but not reported. Foreign liabilities share is the sum of the liabilities of foreign subsidiary banks weighted by the parent bank's ownership share divided by the parent bank's consolidated liabilities. Inflation difference is the difference between foreign inflation and parent-country inflation where foreign inflation is the sum of foreign-country inflation rates weighted by the foreign countries' shares in total foreign liabilities of a parent bank. TBTF is a dummy variable that equals one if a bank's assets in 2000 US dollars are larger than the $90^{\text {th }}$ percentile of the sample. TBTS is a dummy variable that equals one if a bank's liabilities over GDP is larger than the $90^{\text {th }}$ percentile of the sample. Lagged Z-score is an index of bank solvency constructed as (ROA+CAR)/stddev(ROA), where ROA is return on assets, CAR is ratio of capital to assets, and stddev(ROA) is the standard deviation of return on assets. It is calculated for 4-years rolling windows, normalized by total assets, and lagged one period. Lagged profit and Inflation difference are not reported. Bank and year fixed effects are included. Sample period is 1999-2009. Robust standard errors are given in parentheses. *,** and *** denote significance at $10 \%, 5 \%$ and $1 \%$.

\begin{tabular}{|c|c|c|c|c|c|c|}
\hline & \multicolumn{2}{|c|}{ Inflation difference } & \multicolumn{2}{|c|}{ TBTF and TBTS } & \multicolumn{2}{|c|}{ Z-score } \\
\hline & (1) & (2) & (3) & (4) & (5) & (6) \\
\hline Foreign liabilities share & $\begin{array}{c}0.016 * * * \\
(0.006)\end{array}$ & $\begin{array}{c}0.026 * * * \\
(0.007)\end{array}$ & $\begin{array}{c}0.015 * * * \\
(0.005)\end{array}$ & $\begin{array}{c}0.026 * * * \\
(0.007)\end{array}$ & $\begin{array}{c}0.018 * * * \\
(0.005)\end{array}$ & $\begin{array}{c}0.021 * * * \\
(0.006)\end{array}$ \\
\hline Lagged profit*Foreign liabilities share & & $\begin{array}{c}-0.875^{*} \\
(0.491)\end{array}$ & & $\begin{array}{c}-0.905^{*} \\
(0.488)\end{array}$ & & \\
\hline Inflation difference*Foreign liabilities share & $\begin{array}{c}0.410 * * * \\
(0.100)\end{array}$ & $\begin{array}{c}0.400 * * * \\
(0.103)\end{array}$ & $\begin{array}{c}0.409 * * * \\
(0.101)\end{array}$ & $\begin{array}{c}0.399 * * * \\
(0.103)\end{array}$ & $\begin{array}{l}0.326^{*} \\
(0.197)\end{array}$ & $\begin{array}{l}0.339 * \\
(0.201)\end{array}$ \\
\hline TBTF & & & $\begin{array}{c}0.001 \\
(0.002)\end{array}$ & $\begin{array}{c}0.000 \\
(0.002)\end{array}$ & & \\
\hline TBTS & & & $\begin{array}{c}0.006 * * \\
(0.002)\end{array}$ & $\begin{array}{l}0.006^{* * *} \\
(0.002)\end{array}$ & & \\
\hline Lagged Z-score & & & & & $\begin{array}{c}-0.001 \\
(0.001)\end{array}$ & $\begin{array}{c}-0.001 \\
(0.001)\end{array}$ \\
\hline Lagged Z-score*Foreign liabilities share & & & & & & $\begin{array}{l}-0.004 \\
(0.005)\end{array}$ \\
\hline $\mathrm{N}$ & 3719 & 3719 & 3719 & 3719 & 1503 & 1503 \\
\hline R-sq & 0.381 & 0.382 & 0.383 & 0.384 & 0.355 & 0.356 \\
\hline
\end{tabular}


Table 4. Sample split for interest expense regressions by fiscal balance and business cycle interactions

The dependent variable is Interest expense, which is interest expense over bank liabilities excluding non-interest bearing debt. Assets is the natural logarithm of total assets in constant 2000 US dollars. Lagged profit is pre-tax profits divided by total assets, lagged one period. Overhead is personnel expenses and other non-interest expenses over total assets. Short-term debt is ratio of customer and short-term funding over total interest paying debt. Inflation is rate of change in consumer prices. GDP growth is rate of real per capita GDP growth. World GDP growth is the rate of real per capita GDP growth at global level. GDP per capita is GDP per capita in thousands of constant 2000 dollars. These control variables are included in the regressions but not reported. Foreign liabilities share is the sum of the liabilities of foreign subsidiary banks weighted by the parent bank's ownership share divided by the parent bank's consolidated liabilities. Inflation difference is the difference between foreign inflation and parent-country inflation where foreign inflation is the sum of foreign-country inflation rates weighted by the foreign countries' shares in total foreign liabilities of a parent bank. Concentration the sum of the squared shares of bank liabilities weighted by the parent bank's ownership in a country relative to the parent's bank consolidated liabilities for all countries where the parent bank operates. In regressions 6 we require Foreign liabilities share to be less than 0.3. Fiscal balance is the net operating balance calculated as revenues minus expenses of general government over GDP. For regressions 1-2 and 3-4 we create two subsamples on the basis of whether fiscal balance is negative or positive. Bank and year fixed effects are included. Sample period is 1999-2009. Robust standard errors are given in parentheses. *, ** and *** denote significance at $10 \%, 5 \%$ and $1 \%$.

\begin{tabular}{|c|c|c|c|c|c|c|}
\hline \multirow[b]{2}{*}{ Foreign liabilities share } & \multicolumn{2}{|c|}{ Fiscal balance $>0$} & \multicolumn{2}{|c|}{ Fiscal balance $<0$} & \multicolumn{2}{|c|}{$\begin{array}{l}\text { Interactions with world } \\
\text { GDP growth }\end{array}$} \\
\hline & $\begin{array}{c}0.005 \\
(0.007)\end{array}$ & & $\begin{array}{c}0.032 * * * \\
(0.012)\end{array}$ & & $\begin{array}{l}0.020 * * \\
(0.008)\end{array}$ & $\begin{array}{c}0.031 * * * \\
(0.011)\end{array}$ \\
\hline Inflation difference $*$ Foreign liabilities share & $\begin{array}{l}-0.421 \\
(0.564)\end{array}$ & & $\begin{array}{c}0.968 * * * \\
(0.362)\end{array}$ & & $\begin{array}{c}0.408 * * * \\
(0.103)\end{array}$ & $\begin{array}{c}0.423 * * * \\
(0.119)\end{array}$ \\
\hline Concentration & & $\begin{array}{c}-0.006 \\
(0.005)\end{array}$ & & $\begin{array}{c}-0.026 * * * \\
(0.006)\end{array}$ & & \\
\hline World GDP growth * Foreign liabilities share & & & & & $\begin{array}{l}-0.304 \\
(0.273)\end{array}$ & $\begin{array}{c}-0.944 * * \\
(0.403)\end{array}$ \\
\hline $\mathrm{N}$ & 320 & 321 & 1788 & 1787 & 3726 & 3688 \\
\hline $\mathrm{R}-\mathrm{sq}$ & 0.698 & 0.698 & 0.422 & 0.418 & 0.375 & 0.376 \\
\hline Number of banks & 86 & 86 & 581 & 580 & 903 & 900 \\
\hline
\end{tabular}




\section{Table 5. Instrumental variable regressions of interest expense}

The dependent variable is Interest expense, which is interest expense over bank liabilities excluding non-interest bearing debt. Assets is the natural logarithm of total assets in constant 2000 US dollars. Lagged profit is pre-tax profits divided by total assets, lagged one period. Overhead is personnel expenses and other non-interest expenses over total assets. Short-term debt is ratio of customer and short-term funding over total interest paying debt. Inflation is rate of change in consumer prices. GDP growth is rate of real per capita GDP growth. GDP per capita is GDP per capita in thousands of constant 2000 dollars. These control variables are included in the regressions but not reported. Foreign liabilities share is the sum of the liabilities of foreign subsidiary

banks weighted by the parent bank's ownership share divided by the parent bank's consolidated liabilities. Inflation difference is the difference between foreign inflation and parent-country inflation where foreign inflation is the sum of foreign-country inflation rates weighted by the foreign countries' shares in total foreign liabilities of a parent bank. Concentration is the sum of the squared shares of bank liabilities weighted by the parent bank's ownership in a country relative to the parent's bank consolidated liabilities for all countries where the parent bank operates. We estimate all regressions using two-step GMM with country and year fixed effects. The following instruments are used: Tourism which is the total number of tourist arrivals and departures over total population; FDI which is the sum of inward and outward flows of foreign direct investments over GDP; Openness which is the sum of exports and imports of goods and services over GDP; Portfolio position which is the sum of assets and liabilities with respect to a country's portfolio investment position over GDP. Lagged profit and Inflation difference are not reported. We also report the coefficient estimates for the instrumental variables in the first stage regression for Foreign liabilities share, the p-value of the F-test of joint significance of instruments in this first stage regression, the p-value of the Hansen J-test of overidentifying restrictions, the Hausman specification error test of the difference between IV and OLS estimations as an endogeneity test, and the p-value of an LM test regarding the correlation of exogenous instruments with endogenous instrumented variables as a test of underidentification. Sample period is 1999-2009. Standard errors clustered at the bank level are given in parentheses. *,** and *** denote significance at $10 \%, 5 \%$ and $1 \%$.

$\begin{array}{lcc} & (1) & (2) \\ \text { Foreign liabilities share } & 0.094^{* *} & 0.155^{* *} \\ & (0.045) & (0.076) \\ \text { Lagged profit*Foreign liabilities share } & & -4.116 \\ & & (3.091) \\ \text { Inflation difference*Foreign liabilities share } & 1.175^{* *} & 1.193^{* *} \\ \text { Concentration } & (0.518) & (0.515)\end{array}$

(3)

Lagged profit*Concentration

$\begin{array}{ll}(0.029) & -0.114 * * * \\ & (0.042)\end{array}$

2.179

$(1.521)$

First stage regressions:

Tourism

FDI

Openness

Portfolio position

Inflation difference*Tourism

Inflation difference*FD

$\begin{array}{cccc}0.024 * * & 0.022 * & -0.034 * * & -0.034 * \\ (0.011) & (0.012) & (0.017) & (0.018) \\ 0.053 * * & 0.028 & -0.085 * * & -0.055 \\ (0.023) & (0.029) & (0.037) & (0.041) \\ 0.002 & 0.005 & -0.009 & -0.012 \\ (0.021) & (0.021) & (0.036) & (0.036) \\ 0.003 & 0.006 & -0.006 & -0.008 \\ (0.008) & (0.009) & (0.013) & (0.013) \\ 0.079 * & 0.082 * & & \\ (0.046) & (0.045) & & \\ 0.059 & 0.241 & & \end{array}$




\begin{tabular}{|c|c|c|c|c|}
\hline \multirow{3}{*}{ Inflation difference* Openness } & $(0.543)$ & $(0.520)$ & & \\
\hline & -0.072 & -0.079 & & \\
\hline & $(0.092)$ & $(0.093)$ & & \\
\hline \multirow[t]{2}{*}{ Inflation difference*Portfolio position } & -0.055 & -0.069 & & \\
\hline & $(0.061)$ & $(0.060)$ & & \\
\hline \multirow[t]{2}{*}{ Lagged profit*Tourism } & & 0.142 & & -0.073 \\
\hline & & $(0.127)$ & & $(0.195)$ \\
\hline \multirow[t]{2}{*}{ Lagged profit*FDI } & & $2.310^{*}$ & & -2.478 \\
\hline & & $(1.286)$ & & $(1.606)$ \\
\hline \multirow[t]{2}{*}{ Lagged profit*Openness } & & $-0.448 * *$ & & $0.401 *$ \\
\hline & & $(0.205)$ & & $(0.213)$ \\
\hline \multirow[t]{2}{*}{ Lagged profit*Portfolio position } & & -0.287 & & 0.163 \\
\hline & & $(0.177)$ & & $(0.138)$ \\
\hline $\mathrm{N}$ & 2939 & 2939 & 2939 & 2939 \\
\hline R-sq & 0.354 & 0.334 & 0.319 & 0.305 \\
\hline Excluded instruments F-test & 0.024 & 0.011 & 0.005 & 0.013 \\
\hline Hansen J-test (p-value) & 0.239 & 0.485 & 0.249 & 0.402 \\
\hline Endogeneity test (p-value) & 0.139 & 0.109 & 0.009 & 0.008 \\
\hline Underidentification test ( $\mathrm{p}$-value) & 0.049 & 0.019 & 0.078 & 0.110 \\
\hline
\end{tabular}


Table 6. A bank's interest expense and its foreign liabilities during the global financial crisis

The dependent variable is Interest expense, which is interest expense over bank liabilities excluding non-interest bearing debt. Foreign liabilities share is the sum of the liabilities of foreign subsidiary banks weighted by the parent bank's ownership share divided by the parent bank's consolidated liabilities. Crisis is a dummy variable that takes on a value of 1 for the years 2007-2009, and is zero otherwise. Lagged profit is pre-tax profits divided by total assets, lagged one period. Inflation difference is the difference between foreign inflation and parent-country inflation where foreign inflation is the sum of foreign-country inflation rates weighted by the foreign countries' shares in total foreign liabilities of a parent bank. Concentration is the sum of the squared shares of bank liabilities weighted by the parent bank's ownership in a country relative to the parent's bank consolidated liabilities for all countries where the parent bank operates. Lagged profit and Inflation difference are not reported. Regressions include additional control variables as included in the regressions in Table 2 and their interactions with the crisis variable that are not reported. Bank and year fixed effects are included. Sample period is 1999-2009. Robust standard errors are given in parentheses. *,** and *** denote significance at $10 \%, 5 \%$ and $1 \%$.

\begin{tabular}{|c|c|c|c|c|c|c|c|c|}
\hline & (1) & (2) & (3) & (4) & $(5)$ & (6) & (7) & (8) \\
\hline Foreign liabilities share & $\begin{array}{c}0.011 * * * \\
(0.004)\end{array}$ & $\begin{array}{c}0.021 * * * \\
(0.008)\end{array}$ & & & $\begin{array}{c}0.007 \\
(0.005)\end{array}$ & $\begin{array}{c}0.033^{* * *} \\
(0.013)\end{array}$ & & \\
\hline Crisis*Foreign liabilities share & $\begin{array}{c}0.007 \\
(0.007)\end{array}$ & $\begin{array}{c}0.012 \\
(0.015)\end{array}$ & & & $\begin{array}{c}0.001 \\
(0.006)\end{array}$ & $\begin{array}{l}-0.017 \\
(0.014)\end{array}$ & & \\
\hline Lagged profit*Foreign liabilities share & & $\begin{array}{l}-0.808 \\
(0.563)\end{array}$ & & & & $\begin{array}{c}-3.109 * * \\
(1.365)\end{array}$ & & \\
\hline Crisis*Lagged profit*Foreign liabilities share & & $\begin{array}{c}-0.380 \\
(1.528)\end{array}$ & & & & $\begin{array}{c}2.174 \\
(1.467)\end{array}$ & & \\
\hline Inflation difference*Foreign liabilities share & $\begin{array}{c}0.369 * * * \\
(0.109)\end{array}$ & $\begin{array}{c}0.362 * * * \\
(0.112)\end{array}$ & & & $\begin{array}{c}0.244 \\
(0.344)\end{array}$ & $\begin{array}{c}0.131 \\
(0.328)\end{array}$ & & \\
\hline Crisis*Inflation difference*Foreign liabilities share & $\begin{array}{l}-0.078 \\
(0.237)\end{array}$ & $\begin{array}{l}-0.126 \\
(0.252)\end{array}$ & & & $\begin{array}{c}0.465 \\
(0.519)\end{array}$ & $\begin{array}{c}0.584 \\
(0.507)\end{array}$ & & \\
\hline Concentration & & & $\begin{array}{l}-0.010 \\
(0.008)\end{array}$ & $\begin{array}{c}-0.018 * \\
(0.010)\end{array}$ & & & $\begin{array}{c}-0.009 * * \\
(0.004)\end{array}$ & $\begin{array}{c}-0.025 * * * \\
(0.007)\end{array}$ \\
\hline Crisis*Concentration & & & $\begin{array}{c}0.002 \\
(0.013)\end{array}$ & $\begin{array}{c}-0.018 * \\
(0.010)\end{array}$ & & & $\begin{array}{c}-0.004 \\
(0.005)\end{array}$ & $\begin{array}{c}0.007 \\
(0.008)\end{array}$ \\
\hline Lagged profit*Concentration & & & & $\begin{array}{l}0.650^{*} \\
(0.350)\end{array}$ & & & & $\begin{array}{l}1.817 * * \\
(0.730)\end{array}$ \\
\hline Crisis*Lagged profit*Concentration & & & & $\begin{array}{c}1.415 \\
(1.247)\end{array}$ & & & & $\begin{array}{l}-1.274 \\
(0.807)\end{array}$ \\
\hline $\mathrm{N}$ & 3719 & 3719 & 3725 & 3725 & 2021 & 2021 & 2023 & 2023 \\
\hline $\mathrm{R}-\mathrm{sq}$ & 0.381 & 0.382 & 0.351 & 0.357 & 0.440 & 0.442 & 0.440 & 0.442 \\
\hline
\end{tabular}




\section{Table 7. A bank's interest expense and its foreign liabilities during the post-crisis period}

The dependent variable is Interest expense, which is interest expense over bank liabilities excluding non-interest bearing debt. Foreign liabilities share is the sum of the liabilities of foreign subsidiary banks weighted by the parent bank's ownership share divided by the parent bank's consolidated liabilities. Post-crisis is a dummy variable that takes on a value of 1 for the years 2010-2013, and is zero otherwise. Lagged profit is pre-tax profits divided by total assets, lagged one period. Concentration is the sum of the squared shares of bank liabilities weighted by the parent bank's ownership in a country relative to the parent's bank consolidated liabilities for all countries where the parent bank operates. Regressions use data for the entire period of 1999-2013. Regressions 1-4 and 5-8 include additional control variables as in regressions 1-4 of Table 2 that are not reported. Bank and year fixed effects are included. Sample period is $1999-2013$. Robust standard errors are given in parentheses. * $* *$ and $* * *$ denote significance at $10 \%$, $5 \%$ and $1 \%$.

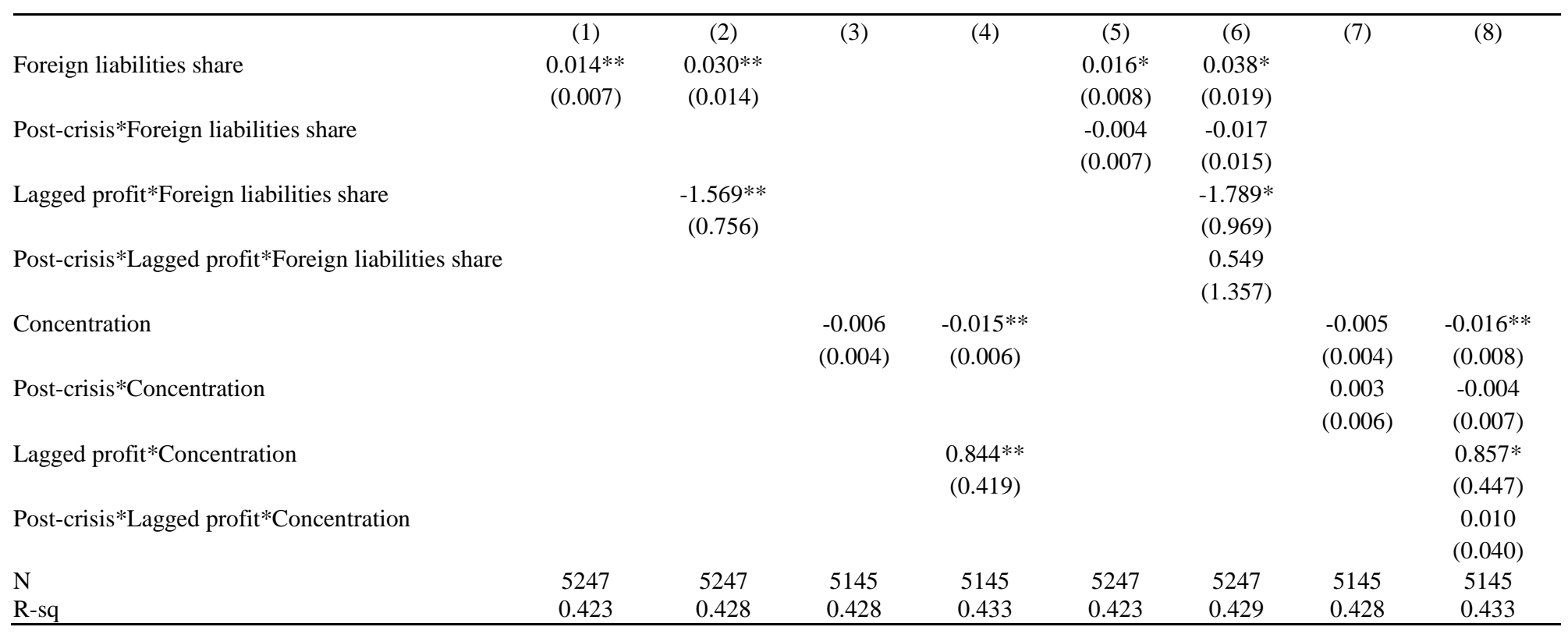




\section{Figure 1. Distribution of a bank's foreign liabilities share}

This figure shows the distribution of Foreign liabilities share, which is the sum of the liabilities of foreign subsidiary banks weighted by the parent bank's ownership share divided by the parent bank's consolidated liabilities. Information in the figure is limited to the 1,316 observations, out of a total of 3,725 observations, with a positive Foreign liabilities share. Two observations with a value higher than 1 are excluded.

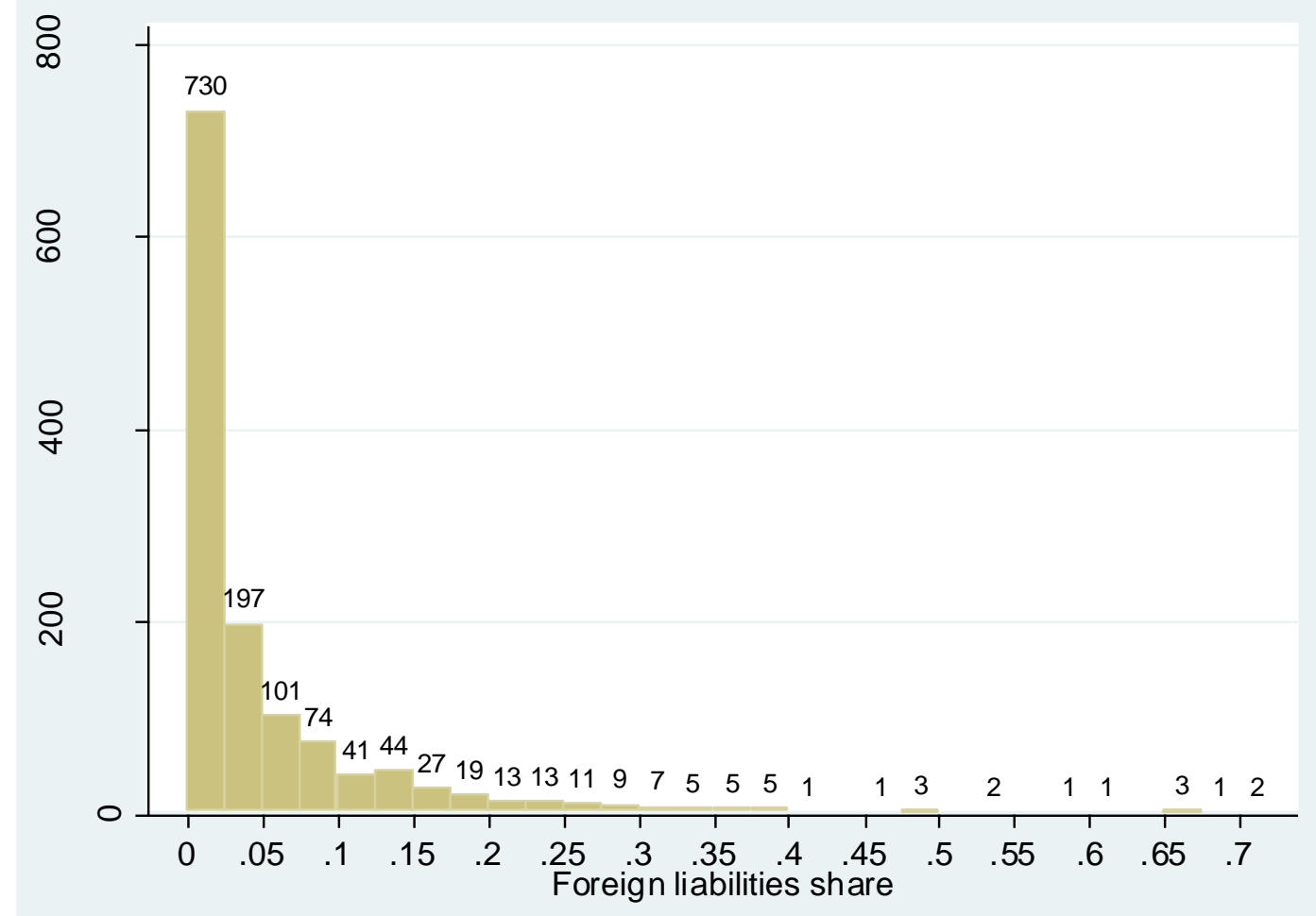




\section{Figure 2. Distribution of a bank's liability concentration}

This figure shows the distribution of Concentration, which is the sum of the squared shares of bank liabilities weighted by the parent bank's ownership in a country relative to the parent's bank consolidated liabilities for all countries where the parent bank operates. Information in the figure is limited to the 1,316 observations, out of a total of 3,725 observations, with a Concentration of less than one, indicating some foreign liabilities. Concentration is not calculated for the two observations with a Foreign liabilities share value higher than one.

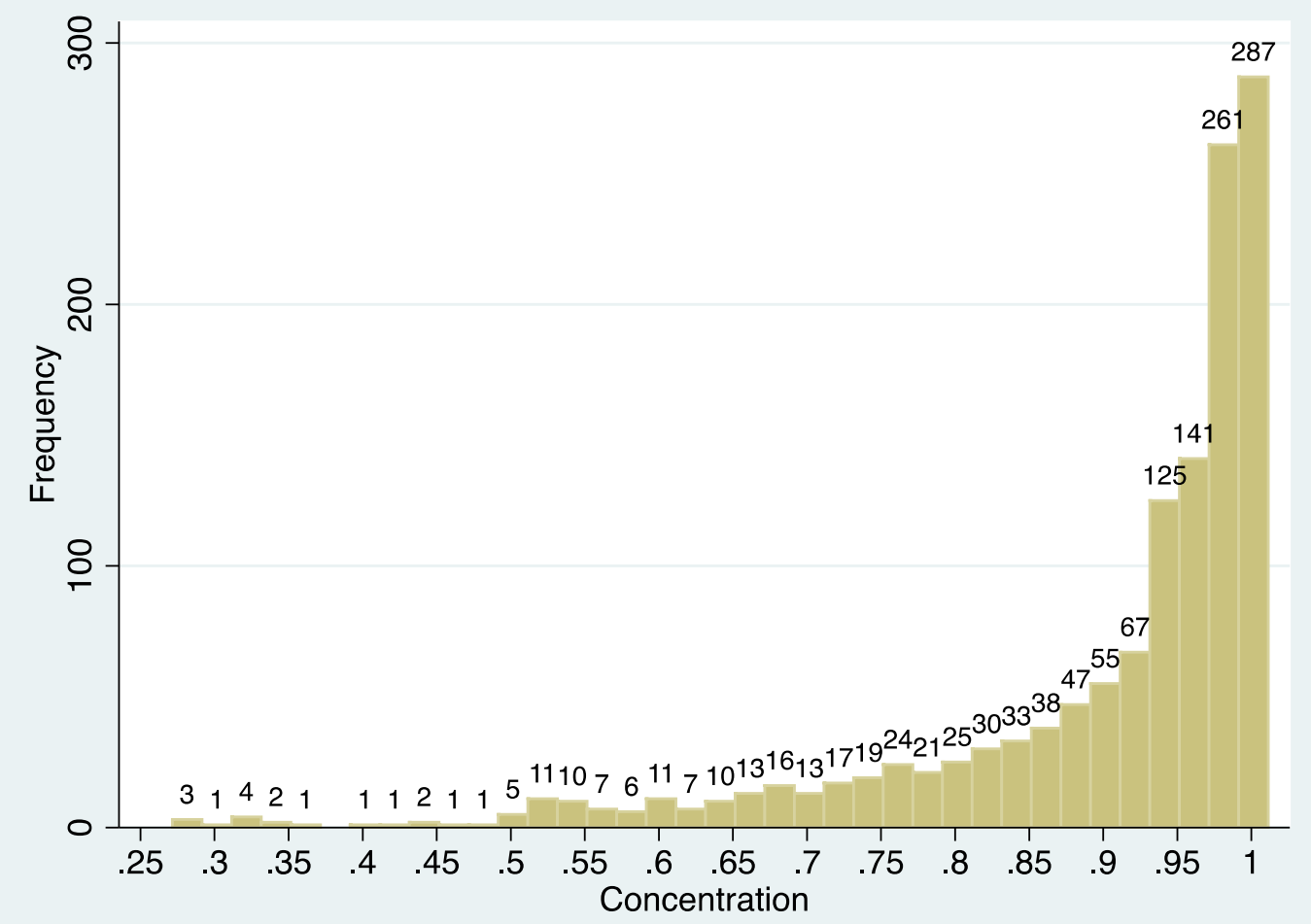

